\title{
W służbie nauce i edukacji polonistycznej (o dokonaniach dydaktyków języka ojczystego w sześćdziesięciolecie działalności Katedry Dydaktyki Języka i Literatury Polskiej)*
}

\author{
In the service of science and teaching the Polish language \\ (about the achievements of the mother tongue teachers \\ in the 60th anniversary \\ of the Chair of Linguistic Didactics and Polish Literature)
}

\begin{abstract}
Summary: The article discusses the contribution of native language teachers to scientific research and educational activities in the 60 years of existence of the Chair of Linguistic Didactics and Polish Literature. Circles of research work are presented, which have been constantly expanded with new issues in connection with cultural, civilization and educational transformations. The results of the research are synthetically discussed - the theories and linguistic methodologies used by the researchers are taken into account. Also, the theoretical and practical significance of publications in the field of language skills, spelling competence of students, word culture and didactic communication as well as the function and language of school textbooks have been outlined. The achievements of educators, which are directly applicable in education, have not been omitted either, e.g. sets of exercises for students, tutorials for teachers.
\end{abstract}

Keywords: Chair of Linguistic Didactics and Polish Literature, Polish Language Didactics

W środowisku akademickim pracownicy Katedry Dydaktyki Języka i Literatury Polskiej zazwyczaj postrzegani są z perspektywy praktycystycznej —

* Tekst przedstawiono w formie referatu podczas uroczystości jubileuszu sześćdziesięciolecia Katedry Dydaktyki Języka i Literatury Polskiej Uniwersytetu Śląskiego 17 czerwca 2019 roku. Katedra ta wskutek reorganizacji uczelni przestała istnieć z dniem 30 września 2019 roku. 
jako osoby, które przygotowują studentów do zawodu nauczycielskiego. Jubileusz sześćdziesięciolecia Katedry jest okazją, by zarysować inne obszary ich działalności: naukowy, badawczy, popularyzatorski, a także zasygnalizować ich wkład w różne subdyscypliny językoznawstwa, w nauczanie języka ojczystego, a ostatnio również w nauczanie języka obcego. Postaram się to przedstawić na przykładzie dokonań zespołu dydaktyków języka (oczywiście, nie tracąc z oczu problemu integrowania działań z dydaktykami literatury).

Twórczyni Katedry Profesor Mieczysława Mitera-Dobrowolska przywiązywała wielką wagę do wychowania językowego'. Będąc doświadczoną nauczycielką szkół średnich, orientowała się w trudnościach językowych uczniów i starała się im zaradzić. Nawiązywała do tradycji szkoły okresu międzywojennego, kiedy to ukształtował się model nauczyciela-badacza (łączącego obowiązki dydaktyczne z pracą naukową) $)^{2}$. Dlatego pozyskiwała do pracy w Katedrze takie osoby, które nie tylko były czynnymi nauczycielami, ale też odznaczały się pasją do naukowego i empirycznego zgłębiania problemów dydaktycznojęzykowych: Jana Cofalika, Irenę Tabakowską, Edwarda Polańskiego, Elżbietę Przyklenk.

Motywacją do organizowania prac badawczych były na początku względy metodyczne. Aby bowiem podejmować decyzje, jak uczyć języka i o języku, dydaktykom potrzebna jest wiedza o uczniu — jego umiejętnościach językowo-komunikacyjnych, procesie przyswajania języka w dzieciństwie, o uwarunkowaniach środowiskowych, kulturowych i innych; potrzebna jest też wiedza o kompetencjach i świadomości językowej nauczyciela oraz przyszłego nauczyciela (studenta), a ponadto - wiedza o procesie dydaktycznym i komunikacji językowej na lekcji oraz z zakresu teorii podręcznika szkolnego.

Profesor Mieczysława Mitera-Dobrowolska wszystkie te problemy brała pod uwagę, proponując $\mathrm{w}$ programie studiów polonistycznych siatkę przedmiotów dydaktycznych. Równolegle z działaniami metodycznymi w Katedrze prowadzono badania empiryczne, których rozwój nastąpił na przełomie lat sześćdziesiątych i siedemdziesiątych XX wieku. W kręgu zainteresowań badawczych znalazły się wówczas sprawność językowa dzieci oraz jej kształcenie ${ }^{3}$, a także

${ }^{1}$ Zob. Z. Adamczykowa: Mieczystawa Mitera-Dobrowolska (1900-1992). Katowice 2006; M. Łojek: Mieczysława Mitera-Dobrowolska. Wzór polonistki na dziś i na jutro. Bydgoszcz 1998.

${ }^{2}$ W latach międzywojennych Mieczysława Miterzanka (Mitera-Dobrowolska), kierująca Ogniskiem Metodycznym Języka Polskiego w Katowicach, podejmowała cenne przedsięwzięcia naukowe, między innymi organizowała wykłady o języku ojczystym i literaturze polskiej, które wygłaszali krakowscy uczeni: Kazimierz Nitsch, Zenon Klemensiewicz, Stanisław Pigoń. Członkowie sekcji naukowej Ogniska włączali się w prace badawcze - gromadzili materiały gwarowe do badań prowadzonych przez Polską Akademię Umiejętności.

3 Zob. J. Cofalik, I. Tabakowska: Ksztaltowanie języka ucznia w procesie nauczania języka polskiego. Warszawa 1963; J. Cofalik, I. Tabakowska, M. Nowakowski: Poprawa 
składnia pisemnych wypowiedzi uczniów, przyczyny niepowodzeń w nauczaniu o języku oraz nauczanie programowane gramatyki ${ }^{4}$.

Dwa duże obszary badawcze (nad ortografią i leksyką dzieci i młodzieży) wytyczył Edward Polański, który harmonijnie łączył pracę naukową ze służbą szkole, z działalnością dydaktyczną i organizacyjną ${ }^{5}$. Prowadził pionierskie badania eksperymentalne nad ortografią uczniów i jej wielorakimi determinantami ${ }^{6}$. Badania te stały się podstawą opracowanej nowatorsko Dydaktyki ortografii i interpunkcji $i^{7}$. Problematykę ortograficzną kontynuowali i wzbogacali nowymi aspektami uczniowie Profesora - głównie magistranci, wśród nich późniejsi pracownicy Katedry: Krystyna Jędrzejczak-Orłowa, Danuta Krzyżyk, Anna Guzy (por. bibliografię). Badano między innymi relacje między wyobraźnią przestrzenną a ortografią, grafią a ortografią, szybkością czytania a sprawnością ortograficzną. Zakres badań poszerzyła o nowe determinanty Danuta Krzyżyk. Interesował ją wpływ współczesnych technologii informatycznych oraz czynników cywilizacyjnych na stan ortografii uczniów. Objęła badaniami między innymi studentów uczących się języka polskiego jako obcego, a także uczniów dysfunkcyjnych (z dysleksją). Wyniki prac stanowiły podstawę zaprojektowania działań dydaktycznych ${ }^{8}$.

W drugim obszarze badań prowadzonych przez pracowników Katedry mieszczą się prace związane z rozwojem leksyki dzieci i młodzieży. Inspiracją do ich podjęcia stała się publikacja Profesora Edwarda Polańskiego pt. Słownic-

wypracowań pisemnych z języka polskiego. Katowice 1957. Por. też opracowanie zagadnień językowych w podręczniku metodycznym dla nauczycieli: J. Cofalik, Z. Nowakowa, E. Polański, E. Przyklenk, I. Tabakowska: Nauczanie języka polskiego w klasie V. Warszawa 1973.

${ }^{4}$ Zob. między innymi: I. Tabakow ska: Trudności sktadni w języku pisanym młodzieży starszych klas szkoły podstawowej. W: Zeszyty Naukowe Katedry Metodyki Literatury i Języka Polskiego WSP nr 1. Katowice 1963; Eadem: Oznajmienie imiesłowowe w języku pisanym uczniów starszych klas szkoły podstawowej na Śląsku. „Język Polski” 1967, z. 2; Eadem: O szkolnych niepowodzeniach w nauczaniu gramatyki i ich źródłach. „Polonistyka” 1964, z. 2; Ead em: Próby programowanego nauczania gramatyki polskiej w szkołach podstawowych województwa katowickiego. W: „Prace Dydaktyczne” VII. Red. J. Cofalik. Katowice 1975.

${ }^{5}$ O dokonaniach Edwarda Polańskiego por. artykuły: H. Synowiec: Stużyć nauce i szkole. Działalność naukowa i dydaktyczna prof. dr. hab. Edwarda Polańskiego. W: W kregu zagadnień dydaktyki języka i literatury polskiej. Red. H. Synowiec. Katowice 2002; M. Łojek: Droga Edwarda Polańskiego do profesury. W: W kręgu...

${ }^{6}$ E. Polański: Badania nad ortografia uczniów. Katowice 1969.

${ }^{7}$ E. Polański: Dydaktyka ortografii i interpunkcji. Wyd. 1. — Warszawa 1987. Wyd. 2. — Warszawa 1995.

${ }^{8}$ Zob. między innymi: D. Krzyżyk: Uczeń w krainie ortografii. W: D. Bula, D. Krzyżyk, B. Niesporek-Szamburska, H. Synowiec: Dziecko w świecie języka. Kraków 2004; D. Krzyżyk: Rozwój umiejętności pisania uczniów z dysleksją rozwojowa-ćwiczenia wspomagające kształcenie kompetencji komunikacyjno-językowej. W: Profilaktyka logopedyczna w praktyce edukacyjnej. T. 2. Red. K. Węsi erska, N. Moćko. Katowice 2013. 
two uczniów. Problemy, badania, wnioski ${ }^{9}$, u jej podstaw legło założenie, że sprawność leksykalna jest istotnym czynnikiem decydującym o sprawności językowo-komunikacyjnej. Kontynuatorzy badań Profesora w latach 1980—1990 opisywali rozwój słownictwa dzieci w ujęciu ilościowym (frekwencyjnym) i jakościowym. Prowadzili przekrojowe badania (od przedszkola po liceum) nad leksyką z wybranych grup znaczeniowych (nazw cech osobowości, nazw uczuć, nazw wartości), korzystając z metod językoznawstwa statystycznego, analizy pól semantyczno-morfologicznych, socjolingwistyki. Prace dostarczyły cennych informacji o przyroście słownictwa na kolejnych etapach rozwoju dzieci, a także o mechanizmach słowotwórczych (np. neologizmach dziecięcych), rozumieniu znaczeń wyrazów, błędach leksykalnych i frazeologicznych, synonimii pojęć prawdziwościowych $)^{10}$. Z czasem zakres badań rozszerzono na frazeologię uczniów (i studentów) oraz na słownictwo i frazeologię tekstów adresowanych do dzieci $^{11}$. Analizowano ponadto zróżnicowanie regionalne i środowiskowe leksyki oraz frazeologii uczniów. Rzetelne prace materiałowe skłaniały autorów do refleksji naukowej i edukacyjnej; przyniosły efekty teoretyczne, a także aplikacyjne, np.: zbiory ćwiczeń, monografię współautorską, dysertację doktorską ${ }^{12}$.

Ustalono zasób frazeologizmów z różnymi komponentami, rozwój rozumienia znaczeń frazeologizmów wśród dzieci i młodzieży, zamierzone i niezamierzone innowacje frazeologiczne w języku uczniów, a ponadto obraz dziecięcego świata utrwalony we frazeologii ${ }^{13}$.

${ }^{9}$ E. Polański: Stownictwo uczniów. Problemy, badania, wnioski. Warszawa 1982.

${ }^{10}$ Por. między innymi: H. Synowiec: Rozwój stownictwa nazywającego cechy osobowości w języku dzieci i młodzieży. Katowice 1985; U. Kopeć: Rozwój słownictwa nazywającego uczucia w języku dzieci i młodzieży (rozprawa doktorska napisana pod kierunkiem Heleny Synowiec. Katowice 1998; opublikowana w roku 2000 w Wydawnictwie Uniwersytetu Rzeszowskiego); D. Krzyżyk: Synonimia pojęć prawdziwościowych. Teoria i nauczanie. Katowice 2008.

${ }_{11}$ Zob. B. Niesporek-Szamburska: Język wierszy dla dzieci (na materiale „Świerszczyka”). Katowice 1990; D. Krzyżyk: Znajomość zwiazków frazeologicznych o rodowodzie mitologicznym (na podstawie badań wśród studentów). W: Język żyje. Rzecz o współczesnej polszczyźnie. Red. K. Ożóg. Rzeszów 2009; H. Synowiec: Uczeń wśród słów, związków frazeologicznych i regionalnych odmian polszczyzny. W: D. Bula, D. Krzyżyk, B. Niesporek-Szamburska, H. Synowiec: Dziecko w świecie języka...

${ }_{12}$ Zob. H. Synowiec: Uczé́ wśród słów...; D. Bula, D. Krzyżyk, B. Niesporek-Szamburska, H. Synowiec: Dziecko w świecie języka...; M. Potaś: Metafora w tekstach pisanych uczniów (praca doktorska napisana pod kierunkiem Heleny Synowiec w roku 2007; opublikowana w roku 2012 w Wydawnictwie Naukowym Uniwersytetu Pedagogicznego); M. Szymańska: Metafory w twórczych wypowiedziach pisemnych uczniów. Kraków 2012.

${ }_{13}$ Zob. między innymi: D. Krzyżyk, H. Synowiec: Z badań nad zwiazkami frazeologicznymi z komponentami nazw barw w języku uczniów (wyniki badań i propozycje dydaktyczne). W: W trosce o dobra edukację. Red. A. Janus-Sitarz. Kraków 2009; H. Synowie c: Problemy frazeologii w kształceniu językowym uczniów. W: Wiedza o języku i kompetencje językowe uczniów. Red. B. Nies porek-Szamburska. Katowice 2012; B. Niesporek-Szamburska: Językowy obraz pór roku i tradycji kulturowych w twórczości dzieci. Katowice 2004. 
Trzeba zaznaczyć, że podejmowane przez badaczy problemy stale pogłębiano i poszerzano, rozpatrując inne aspekty. Odkrywano też nowe perspektywy badań - z jednej strony w związku z rozwojem teorii językoznawczych (np. pragmalingwistyki, kognitywizmu ${ }^{14}$, a $\mathrm{z}$ drugiej strony w związku ze szkolną rzeczywistością zmieniającą się pod wpływem czynników cywilizacyjno-kulturowych ${ }^{15}$. Nawet jeśli zagadnienia badawcze były ,wymuszane” czynnikami instytucjonalnymi (np. oświatowymi — kolejnymi reformami edukacji, modyfikacjami podstawy programowej, a jeszcze wcześniej — programów nauczania), to wypracowane w toku prac narzędzia i techniki okazały się użyteczne również w późniejszym okresie, skutecznie służąc penetrowaniu nowych płaszczyzn badań ${ }^{16}$.

Przez wiele lat prowadzono w Katedrze prace nad sprawnością językowo-komunikacyjną i różnymi jej komponentami (poprawnością, stosownością wypowiedzi, etyką słowa). Wykorzystywano do tych celów nie tylko metodologię socjolingwistyczną oraz pragmalingwistyczną, ale też osiągnięcia glottodydaktyki, zwłaszcza w badaniach nad „przełączaniem” kodu językowego wśród dzieci ze środowisk gwarowych ${ }^{17}$. O sprawnościach tych dzieci traktowały liczne artykuły, osobna monografia oraz współautorskie publikacje dydaktycznojęzykowe $^{18}$.

${ }^{14}$ Zob. B. Niesporek-Szamburska: Językowy obraz czterech pór roku...; D. Bula, B. Niesporek-Szamburska: Zachowania językowe młodzieży — błędy w komunikacji czy celowa manifestacja?. W: Język trzeciego tysiąclecia 2. T. 1: Nowe oblicze komunikacji we wspótczesnej polszczyźnie. Red. G. Szpila. Kraków 2002.

15 Zob. H. Synowiec: Stan polszczyzny uczniów na tle przemian kulturowych i cywilizacyjnych. W: Język polski jako narzędzie komunikacji we wspótczesnym świecie. Red. J. Mazur, M. Rzeszutko-Iwan. Lublin 2007; B. Niesporek-Szamburska: Media elektroniczne a język ucznia. W: Ksztatcenie językowe w dobie kultury masowej polisensorycznej. Red. U. Kopeć, Z. Sibiga. Rzeszów 2010.

16 Przykładowo: na przełomie lat osiemdziesiątych i dziewięćdziesiątych XX wieku zespół pracowników Katedry uczestniczył w badaniach wdrożeniowych (tzw. węzłowych) nad programem nauczania języka polskiego dziesięcioletniej szkoły podstawowej. Opracowane wówczas kwestionariusze obserwacji lekcji, wzory testów, kryteria oceny podręczników, analizy procesu dydaktycznego - poddane krytycznej refleksji — były stosowane w dalszych badaniach nad funkcjonalnym nauczaniem o języku, sprawnością komunikacyjną, modelami podręczników, integrowaniem treści kształcenia itp.

17 Zob. H. Synowiec: O przydatności badań glottodydaktycznych $w$ nauczaniu języka ojczystego w środowiskach gwarowych. „Języki Obce w Szkole” 2001, nr 6; B. Niesporek-Szamburska: Język pierwszy dziecka — od nabywania do kształcenia kompetencji językowej i komunikacyjnej. W: Lingwistyka stosowana. T. 3. Red. S. Grucza. Warszawa 2010.

18 Zob. H. Synowiec: Sprawność językowa uczniów w śląkim środowisku gwarowym. Problemy, badania, konsekwencje dydaktyczne. Katowice 1992. Por. współautorskie artykuły B. Cząstki-Szymon i H. Synowiec oraz zbiory ćwiczeń tychże autorek, uwzględnione w bibliografii (por. też Zestawienie publikacji i ważniejszych osiagnięć KDJiLP na końcu tomu). 
Teorie pragmalingwistyczne zaadaptowane do opisu komunikacji dydaktycznej — dyskursu szkolnego, dialogu i współdziałania nauczyciela z uczniami na lekcji, zaowocowały badaniami Urszuli Żydek-Bednarczuk, Bogusława Skowronka i Olgi Przybyli ${ }^{19}$. Autorzy analizowali modele komunikowania się nauczyciela z uczniami w trakcie lekcji, rozpatrywali takie szczegółowe kwestie, jak: akty mowy nauczyciela, pytania i polecenia kierowane do ucznia, sposoby wyrażania różnych intencji komunikacyjnych przez uczniów, uwarunkowania sytuacyjne w porozumiewaniu się młodzieży na lekcji i poza nią ${ }^{20}$. Rezultaty badań znacznie poszerzyły wcześniejsze ustalenia pedagogów dotyczące dominującej roli nauczycieli na lekcji. Zauważono na przykład dysonans między potrzebą autentycznej rozmowy ucznia z nauczycielem a koniecznością ,realizowania" na lekcji treści nauczania, opisano próby przełamywania barier komunikacyjnych między uczniem a uczącymi na lekcji.

Problemy związane z komunikacją językową korelowano z badaniami nad kulturą języka w szkole: poprawnością, stosownością wypowiedzi i etyką słowa uczniów, nauczycieli, studentów ${ }^{21}$.

Badacze zwracali uwagę na rozdźwięk między skutecznością komunikacyjną, preferowaną przez użytkowników polszczyzny, a poprawnością językową wypowiedzi (nierespektowanie normy wzorcowej) oraz na takie niepokojące zjawiska, jak: nasilająca się kolokwializacja i wulgaryzacja języka, ,mieszanie” stylów, a przede wszystkim nieetyczne zachowanie językowe. Próbowano ustalić, jak młodzież rozumie pojęcia kultury języka i etyki słowa ${ }^{22}$. Wyniki badań

19 Zob. U. Żydek-Bednarczuk, B. Zeler: Strategia i komunikacja w dyskursie edukacyjnym. W: Dyskurs edukacyjny. Red. T. Rittel. Kraków 1996; U. Żydek-Bednarczuk: Uczeń i nauczyciel w świecie dyskursów. W: „Studia Pragmalingwistyczne”. T. 5: Mowa i język w perspektywie dydaktycznej, logopedycznej i rozwojowej. Red. J. Porayski-Pomsta. Warszawa 2008; B. Skow ronek: O dialogu na lekcjach w szkole średniej. Analiza pragmatycznojęzykowa. Kraków 1999 (w 1998 roku autor obronił rozprawę doktorską na ten temat, przygotowaną pod kierunkiem Heleny Synowiec); O. Przybyla: Akty mowy w języku nauczyciela. Katowice 2004.

${ }^{20}$ Zob. między innymi: D. Bula, B. Niesporek-Szamburska: Zachowania językowe mtodzieży...

${ }^{21}$ Zob. H. Synowiec: Kultura języka nauczycieli w sytuacji lekcyjnej. W: Dyskurs edukacyjny. Red. T. Rittel. Kraków 1996; H. Synowiec: O kulturze języka we współczesnej szkole. W: $W$ kręu polszczyzny dawnej a wspótczesnej. Red. E. Kołodziejek. Szczecin 2006; A. Rypel: Nauczanie komunikacyjne w kształceniu uczniowskich wypowiedzi pisemnych. Problemy. Badania eksperymentalne. Implikacje dydaktyczne (rozprawa doktorska napisana pod kierunkiem Heleny Synowiec. Katowice 2000; opublikowana w roku 2000 w Wydawnictwie Akademii im. Kazimierza Wielkiego w Bydgoszczy); D. Krzyżyk, H. Synowiec: O btędach w pisemnych wypowiedziach polonistów (na podstawie analizy opinii o studentach). W: Norma językowa $w$ aspekcie teoretycznym i praktycznym. Red. A. Piotrowicz, M. Witaszek-Samborska, K. Skibski. Poznań 2011.

${ }^{22}$ Zob. D. Krzyżyk, H. Synowiec: Etyka słowa w rozumieniu młodzieży. W: Etyka słowa. Wybór opracowań. Red. J. Bartmiński, S. Niebrzegowska-Bartmińska, M. Nowosad-Bakalarczyk, J. Puzynina. Lublin 2017. 
prezentowano w monografiach oraz na posiedzeniach Komisji Dydaktycznej Rady Języka Polskiego przy Prezydium PAN ${ }^{23}$.

Zanim w 2008 roku władze oświatowe przeorientowały podstawę programową w stronę tekstocentryzmu, pracownicy Katedry już o wiele wcześniej interesowali się badawczo gatunkami wypowiedzi tworzonymi przez uczniów i do nich adresowanymi ${ }^{24}$. Analizowali umiejętności tekstotwórcze uczniów (a potem też nauczycieli), uwzględniając między innymi spójność wypowiedzi pisemnych. Badali również dziecięcą percepcję tekstów o różnych funkcjach: poetyckiej, dydaktycznej, popularnonaukowej, religijnej. Badania nad strukturą i kompozycją tekstów, jako wyznacznikami kompetencji gatunkowej młodzieży, dostarczyły istotnych dla dydaktyki języka ustaleń dotyczących semantycznych i pragmatycznych cech wypowiedzi uczniowskich, zakłóceń kompozycyjnych, trudności w budowaniu spójnych tekstów i przyczyn tych trudności ${ }^{25}$, a ponadto - posługiwania się przez uczniów metaforyką (w tym metaforą synestezyjną) $)^{26}$.

Nowe perspektywy badawcze otworzyła przed dydaktykami języka teoria językowego obrazu świata ${ }^{27}$. Nawiązując do tej teorii, rekonstruują oni utrwalone w werbalnych i niewerbalnych tekstach uczniowskich obrazy rzeczywistości.

${ }^{23}$ W latach 2003-2009 funkcję przewodniczącej tej Komisji (później Zespołu Dydaktycznego) pełniła Helena Synowiec, a funkcję sekretarza - Danuta Krzyżyk.

${ }^{24}$ Zob. U. Żydek-Bednarczuk: Opowiadania szkolne $w$ świetle diagnozy dydaktycznej. W: „Z Teorii i Praktyki Dydaktycznej Języka Polskiego”. T. 15. Red. E. Polański, Z. Uryga. Katowice-Kraków 1999; B. Niesporek-Szamburska: Literatura fantasy w edukacji polonistycznej. W: Kultura, literatura i sztuka w edukacji językowej $w$ świetle badań empirycznych. Red. J. Kida. Rzeszów 2007; B. Niesporek-Szamburska: Wiersze dla dzieci jako komunikat w prasie (na przyktadzie „Świerszczyka”). W: „Język Artystyczny”. T. 5. Red. A. Wilkoń. Katowice 1987; H. Synowiec: Sposoby popularyzowania polszczyzny pięknej i poprawnej w poradnikach językowych dla dzieci i młodzieży. W: Lektury pokoleniowe i ponadpokoleniowe. Z zagadnień recepcji. Red. I. Socha. Katowice 2012; D. Krzyżyk, H. Synowiec: Homilie dla dzieci. Spojrzenie językoznawcy. W: Słowo, obraz, dźwięk w mszach świętych z udziałem dzieci. Red. H. Sławiński, W. Przyczyna. Kraków 2019; D. Krzyżyk, H. Synowiec: Teksty hagiograficzne dla dzieci w „Małym Gościu Niedzielnym”. W: ,Stare i nowe” w literaturze dla dzieci i młodzieży. Biografie. Red. B. Olszewska, O. Pajączkowski, L. Urbańczyk. Opole 2015.

${ }^{25}$ Między innymi: D. Krzyżyk: Wyznaczniki spójności tekstu w pracach pisemnych maturzystów. W: Biuletyn maturalny OKE w Jaworznie. Cz. 2. Jaworzno 2007; Eadem: Umiejętności tekstotwórcze i językowe uczniów w pisemnych wypowiedziach maturalnych. W: Kształcenie językowe w dobie kultury masowej polisensorycznej. Red. U. Kopeć, Z. Sibiga. Rzeszów 2010.

${ }^{26}$ Zob. B. Niesporek-Szamburska: O metaforze synestezyjnej $w$ tekstach dzieci. W: „Z Teorii i Praktyki Dydaktycznej Języka Polskiego”. T. 18. Red. H. Synowiec. Katowice 2005.

${ }^{27}$ Zob. T. Zgółka: Kształcenie językowe a językoznawstwo współczesne. W: Zjazd polonistów 1995. (Zagadnienia edukacyjne). Red. B. Chrząstowska, Z. Uryga. Kraków 1995; Językowy obraz świata. Red. J. Bartmiński. Lublin 1990; J. Bartmiński: O pojęciu językowego obrazu świata. W: Idem: Językowe podstawy obrazu świata. Lublin 2006; Idem: Miejsce wartości w językowym obrazie świata. W: Język w kręgu wartości. Studia semantyczne. Red. J. Bartmiński. Lublin 2003. 
Publikacje Bernadety Niesporek-Szamburskiej i Danuty Krzyżyk, będące efektem badań empirycznych, zaznajamiają ze sposobami postrzegania i wartościowania przez dzieci i młodzież zjawisk przyrody (pór roku, żywiołów), tradycji kulturowych, postaci baśniowych i wywodzących się z mitologii ludowej (strzygi, czarownicy, Skarbnika) ${ }^{28}$. Ponadto badania D. Krzyżyk uwzględniają istotne kwestie aksjologiczne - rozumienie pojęć prawdziwościowych i projekcję przyszłego domu rodzinnego przez nastolatków ${ }^{29}$.

$\mathrm{Z}$ kolei dogłębnie zanalizowane przez badaczki teksty kultury (np. utwory dziecięce, pieśni ludowe pod kątem wpisanych w nie obrazów) mogą stanowić dla nauczycieli merytoryczną i metodologiczną podstawę działań interpretacyjnych, ale też wyzwalania w uczniach inwencji twórczej3.

Rozległą płaszczyznę wieloletnich badań dydaktyków stanowiły podręczniki szkolne - ich koncepcje, funkcje, język (zwłaszcza komunikatywność mierzona za pomocą specjalnych narzędzi $)^{31}$. W Katedrze przygotowano monografię zbiorową — studium o podręcznikach do kształcenia polonistycznego $^{32}$, a ponadto na zlecenie Rady Języka Polskiego opracowano raporty o języku podręczników i o terminologii w podręcznikach do różnych przedmiotów (też do przedmiotów zawodowych). Raporty te Komisji Senackiej RP przedstawił Profesor Andrzej Markowski, przewodniczący Rady Języka Polskiego. Współ-

${ }^{28}$ Zob. B. Nies porek-Szamburska: Językowy obraz pór roku...; Eadem: Stereotyp czarownicy i jego modyfikowanie. Na przyktadzie tekstów dla dzieci $i$ wypowiedzi dziecięcych. Katowice 2013; D. Krzyżyk: Odzwierciedlenie języka i kultury regionu w pieśniach górniczych. W: „Z Teorii i Praktyki Dydaktycznej Języka Polskiego”. T. 20. Red. H. Synowiec. Katowice 2009.

${ }^{29}$ Zob. D. Krzyżyk: Językowy obraz prawdy w wypowiedziach młodzieży szkót średnich. W: „Z Teorii i Praktyki Dydaktycznej Języka Polskiego”. T. 16. Red. H. Synowiec. Katowice 2001; D. Krzyżyk, H. Synowiec: Językowa projekcja domu rodzinnego w wypowiedziach mtodzieży śląskiej. W: Rodzina, wychowanie, wielokulturowość. Red. T. Lewowicki, J. Suchodolska. Cieszyn 2000.

${ }^{30}$ Między innymi: D. Krzyżyk: Językowo-kulturowy obraz św. Barbary w pieśniach religijnych i powszechnych. W: Dziedzictwo kulturowo-historyczne regionu. Red. A. Królikowska. Kraków 2013; D. Krzyżyk: Pedagogika międzykulturowa i regionalna; Eadem: Pieśni dla Dziecka i o Dziecku. Cud narodzin Boga w kolędach polskich (wybrane motywy). W: Dziecko - język - tekst. Red. B. Niesporek-Szamburska, M. Wójcik-Dudek. Katowice 2010; D. Krzyżyk: Wizerunek górnika w przysłowiach. W: Ex pago Silensi. Red. M. Kisiel, T. Sierny. Katowice 2011; H. Synowiec: Wizerunek myśliwego w pieśniach ludowych. W: Wokót kultury myśliwskiej. Szkice o tradycjach łowieckich ziemi pszczyńskiej. Red. J. Uchyła-Zroski, R. Solik. Pszczyna 2008.

${ }^{31}$ Zob. K. Gąsiorek: Komunikatywność (czytelność) podręczników literatury a język uczniów w szkole średniej. W: Podręczniki literatury w szkole średniej. Red. B. Chrząstowska. Poznań 1991. Obecnie wykorzystywane są ogólnodostępne aplikacje, za pomocą których oblicza się indeks mglistości. http://www.logios.pl oraz http://jasnopis.pl/aplikacja. Por. Jasnopis, czyli mierzenie zrozumiałości polskich tekstów urzędowych. Red. W. Gruszczyński, M. Ogrodniczuk. Warszawa 2015.

32 Zob. Podręczniki do kształcenia polonistycznego w zreformowanej szkole - koncepcje, funkcje, język. Red. H. Synowiec. Katowice 2007. 
autorsko opracowano na zlecenie MEN przewodnik dla autorów i wydawców podręczników oraz kryteria oceny podręcznika dla rzeczoznawców (por. bibliografię). Po upływie kilkudziesięciu lat pracownicy Katedry są już autorami (lub współautorami) podręczników do kształcenia językowego dla różnych etapów edukacyjnych (por. wykaz literatury w Zestawieniu publikacji...), są także rzeczoznawcami MEN do oceny podręczników szkolnych pod względem językowym. W ramach prac Komisji do Oceny Podręczników Szkolnych PAU jej członkinie: Ewa Ogłoza, Danuta Krzyżyk i Helena Synowiec przedstawiają opinie o podręcznikach do kształcenia polonistycznego funkcjonujących w szkołach, opracowują również rozprawy i szkice o charakterze teoretycznym ${ }^{33}$.

Bliskie praktyce dydaktycznej są zainteresowania kulturą żywego słowa ${ }^{34}$, emisją głosu i logopedią. Wkład w te dziedziny wnoszą: Danuta Krzyżyk, zajmująca się sztuką recytacji, Anna Guzy, którą — oprócz sztuki recytacji — interesują kwestie diagnozowania i jakości emisji głosu nauczycieli i studentów, a także rola ortofonii w kształceniu obcokrajowców ${ }^{35}$, oraz Olga Przybyla, podejmująca kwestie diagnozy i terapii logopedycznej. Te same badaczki poświęcają uwagę trudnościom językowo-komunikacyjnym uczniów dysfunkcyjnych (o specjalnych potrzebach edukacyjnych) ${ }^{36}$. Wymagają oni bowiem dostosowania warunków dydaktycznych (np. celów, treści, metod i technik nauczania) do indywidualnych cech rozwoju i możliwości wychowanków. Autorki koncentrują uwagę na problemach językowych i komunikacyjnych dzieci z zaburzeniami

${ }^{33}$ Zob. D. Krzyżyk: Odzwierciedlenie funkcji podręcznika w języku i stylu. W: „Opinie Edukacyjne Polskiej Akademii Umiejętności - Prace Komisji PAU do Oceny Podręczników Szkolnych". T. 13. Kraków 2015; D. Krzyżyk, H. Synowiec: Tytuły podręczników do ksztatcenia polonistycznego - ich formuly i funkcje. W: „Opinie Edukacyjne...”. T. 15. Kraków 2017; Eaedem: Podręcznik szkolny — pomoc czy przeszkoda w opanowaniu wiedzy i umiejętności (komunikatywność i funkcjonalność)?. W: Oblicza polszczyzny. Red. A. Markowski, R. Pawelec. Warszawa 2012.

${ }^{34}$ Początki tych zainteresowań sięgają w Katedrze lat sześćdziesiątych XX wieku, kiedy to zajęcia z kultury żywego słowa prowadził ze studentami polonistyki mgr Marian Mikuta — autor książki Kultura żywego słowa, i scenariuszy teatralnych, opiekun teatru studenckiego. W latach siedemdziesiątych —osiemdziesiątych współpracował z Katedrą dr Jerzy Kram — autor publikacji Gawędy o żywym słowie i Zarys kultury żywego słowa, pracownik Oddziału Doskonalenia Nauczycieli w Katowicach, współredaktor tomów 3.-6. wydawnictwa ciągłego „Z Teorii i Praktyki Dydaktycznej Języka Polskiego".

${ }^{35}$ Zob. A. Guzy: Jakość emisji głosu przyszłych nauczycieli. W: Językowe, literackie i kulturowe ścieżki edukacji polonistycznej (tradycje $i$ wspótczesność). Red. B. Niesporek-Szamburska, D. Krzyżyk. Katowice 2014; A. Guzy: Problemy głosowe nauczycieli. W: Zdrowie w perspektywie pedagogicznej. Red. D. Umiastowska, J. Gebreselassie. Gorzów Wielkopolski 2012; B. Niesporek-Szamburska, D. Krzyżyk: Rola ortofonii w edukacji obcokrajowców - rozwiazania praktyczne. W: Polska i Polacy w badaniach młodych naukowców. Red.

N. Kryłowa, T. Goli-Ogłu, T. Naumowa, A. Izaszko, J. Jędrysiak. Mariupol 2009.

${ }^{36}$ Zob. Praca z uczniem o specjalnych potrzebach edukacyjnych. T. 1. Red. A. Guzy, D. Krzyżyk. Kielce 2012; T. 2. Red. A. Guzy, B. Niesporek-Szamburska. Kielce 2013. 
percepcji przestrzennej (Anna Guzy) oraz z zaburzeniami percepcji słuchowej (o obniżonym poziomie słuchu fonetycznego), a ponadto - z zespołem Aspergera i dysleksją rozwojową (Danuta Krzyżyk). Opisują trudności i błędy, przedstawiają zasady postępowania na lekcjach i typy ćwiczeń usprawniających zaburzone funkcje. Badania znajdują zastosowanie w dydaktyce szkoły wyższej (przygotowaniu studentów do pracy z uczniami dysfunkcyjnymi); ich wyniki autorki popularyzują wśród nauczycieli (warsztaty zajęciowe, prelekcje).

Istotne znaczenie dla środowiska regionalnego (śląskiego) mają podejmowane w Katedrze od dawna zagadnienia związane $\mathrm{z}$ edukacją regionalną (w perspektywie tradycji lat międzywojennych i współczesności) ${ }^{37}$, zwłaszcza z dziedzictwem kulturowym, którego nośnikiem jest dialekt śląski, pełniący nie tylko funkcję komunikacyjną, ale też kulturotwórczą i wspólnototwórczą, estetyczną i artystyczną (między innymi teksty folkloru). Prowadzone od lat osiemdziesiątych XX wieku badania, także prace dyplomowe studentów, mające charakter empiryczny, poświadczają bogactwo leksykalne i zróżnicowanie wewnętrzne gwar śląskich ${ }^{38}$. Wymiernym efektem badań są opracowania monograficzne (np. słownik gwarowy Górnego Śląska), popularnonaukowe i dydaktyczne (zbiory ćwiczeń, poradniki dla nauczycieli - por. Zestawienie publikacji...). Służą one zarówno celom językoznawczym, jak i praktyce szkolnej oraz środowisku lokalnemu $^{39}$. Zresztą w działalności naukowo-badawczej niemal wszystkich pracowników Katedry można zaobserwować, jak praktyka szkolna przenika się z różnymi dziedzinami językoznawstwa i otwiera nowe domeny badań empirycznych, których wyniki stają się z kolei uzasadnieniem decyzji metodycznych. Równocześnie badania diagnostyczne pozwalają między innymi prognozować rozwój zjawisk językowych we współczesnej polszczyźnie, wskazywać tendencje do zanikania lub nasilania się pewnych form gramatycznych w języku uczniów, a także postaw młodych ludzi wobec języka.

Nie można pominąc prac, które wpisują się w blok zagadnień związanych bezpośrednio z procesem dydaktycznym - psychologiczną podbudową tego procesu, organizacją kształcenia polonistycznego, z integracją celów i treści kształcenia, a także z opracowaniem narzędzi diagnostycznych (np. kwestiona-

${ }^{37}$ Zob. H. Synowiec: Śląska ojczyzna polszczyzna z perspektywy edukacyjnej. Katowice 2013; Eadem: Śląskie czasopisma szkolne (1922-1938). Katowice 1999.

${ }^{38}$ Zob. między innymi B. Cząstka-Szymon, H. Synowiec: Charakterystyka gwar ślaskich na tle zróżnicowania dialektalnego województwa śląskiego... Por. też szerzej: H. Synowiec: Zróżnicowanie terytorialne polszczyzny a edukacja językowa. W: Odmiany polszczyzny w szkole. Teoria i praktyka. Red. H. Synowiec przy współpracy M. Kubarek. Katowice 2013.

${ }^{39}$ Między innymi zaangażowanie w wydarzenia o zasięgu regionalnym: H. Synowiec i D. Krzyżyk uczestniczą w pracach jury konkursów gawędziarskich i recytatorskich w gwarze, są redaktorkami i konsultantkami merytorycznymi wydawnictw pokonkursowych. Zob. np. D. Krzyżyk, W. Leś, H. Synowiec: Spotkania z gwara i kulturą regionu. Konkurs recytatorski w gwarze śląskiej Śląska Ojczyzna Polszczyzna. Mysłowice 2007. 
riuszy obserwacji lekcji). Tymi zagadnieniami zajmowali się w ciągu kilkudziesięciu lat liczni pracownicy Katedry: Ewa Ogłoza, Krystyna Orłowa, Jadwiga Bednarkowa, Jerzy Budzik, a ponadto - współpracująca z Katedrą nauczycielka, wizytatorka i doradczyni metodyczna Lidia Gilowa. Obecnie wiele uwagi pracownicy Katedry poświęcają jakości kształcenia studentów oraz różnym aspektom procesu kształcenia uniwersyteckiego — dydaktyce szkoły wyższej ${ }^{40}$.

W upowszechnianiu teoretycznych i badawczych problemów edukacji językowej, podejmowanych przez pracowników Katedry Dydaktyki w ciągu sześćdziesięciu lat jej działalności ważną rolę odgrywały (i odgrywają) cykliczne publikacje i czasopisma, nad którymi opiekę naukową sprawowali dydaktycy: „Zeszyty Naukowe” (Sekcja Językoznawstwa katowickiej WSP - 1959, 1969), „Prace Dydaktyczne” (t. 7 - 1975), skrypty Z Pomoca Poloniście (t. 1 - 1964, t. 2 - 1968), a przede wszystkim ukazujące się od ponad czterdziestu lat wydawnictwo ciągłe ,Z Teorii i Praktyki Dydaktycznej Języka Polskiego"41. Oprócz tego powstały liczne naukowe monografie zbiorowe pod redakcją pracowników Katedry (por. Zestawienie publikacji...). Efekty prac badawczych prezentowano również na ogólnopolskich i międzynarodowych konferencjach, przede wszystkim na cyklicznie organizowanej w Krakowie Jesiennej Szkole Dydaktyków ${ }^{42}$.

W tematyce artykułów i referatów śląskich dydaktyków języka odbijały się przeobrażenia zachodzące $\mathrm{w}$ edukacji polonistycznej, zainteresowania badawcze autorów, między innymi różnymi aspektami kształcenia językowego w szkole, przygotowaniem studentów do zawodu nauczycielskiego w związku ze zmianami w systemie oświaty itp.

Nie sposób pominąć bogatego dorobku pracowników Katedry służącego bezpośrednio praktyce polonistycznej — słowników, materiałów dydaktycznych, serii podręczników do kształcenia językowego na różnych etapach edu-

${ }^{40}$ Zob. Pedagogika szkolna. Materiaty dla studentów przygotowujacych się do wykonywania zawodu nauczyciela. Red. D. Krzyżyk, B. Niesporek-Szamburska przy współpracy A. Zok-Smoły. Katowice 2014.

${ }^{41}$ Ukazuje się od 1977 roku; jego powołanie było wynikiem współpracy ówczesnego Zakładu Dydaktyki Literatury i Języka Polskiego, kierowanego przez E. Polańskiego, z Instytutem Kształcenia Nauczycieli i Badań Oświatowych (późniejszy Oddział Doskonalenia Nauczycieli i Wojewódzki Ośrodek Metodyczny) reprezentowanym przez Jerzego Krama. Cele i koncepcje zostały odzwierciedlone w tytule pisma - miało ono służyć diagnozowaniu i prognozowaniu dydaktycznemu, weryfikowaniu naukowych i teoretycznych założeń dydaktyki, stanowić teoretyczną i metodologiczną podstawę praktyki szkolnej. Por. przegląd problemów podejmowanych na łamach wydawnictwa ciągłego zamieszczony we Wstepie E. Ogłozy i H. Synowiec do tomu 20. „Z Teorii i Praktyki Dydaktycznej Języka Polskiego”. Katowice 2009.

${ }^{42}$ Twórcą ogólnopolskiej Jesiennej Szkoły Dydaktyków zainicjowanej w roku 1980, odbywającej się co dwa lata w krakowskiej WSP (a później na Uniwersytecie Pedagogicznym), był dydaktyk literatury prof. dr hab. Zenon Uryga (rektor uczelni), a we współorganizowanie byli zaangażowani pracownicy Zakładu Metodyki Języka Polskiego WSP: Anna Dyduchowa, Halina Kosętka, Maria Jędrychowska, Maria Sienko. 
kacyjnych, także do nauczania języka polskiego jako drugiego w środowiskach polonijnych, przewodników dla nauczycieli, zbiorów ćwiczeń słownikowych, frazeologicznych i ortograficznych oraz ćwiczeń językowo-komunikacyjnych (i przewodnika dydaktycznego) przeznaczonych dla uczniów ze środowisk gwarowych (por. literaturę w Zestawienie publikacji...).

Dodajmy, że dydaktyków języka katowickiej uczelni cechuje szczególna troska o kulturę językowego obcowania nie tylko w szkole, ale też w różnych kręgach społecznych. Dlatego podejmowali i podejmują oni różne przedsięwzięcia mające na celu podniesienie poziomu kultury języka i etyki słowa: prelekcje, pogadanki, cykle spotkań z okazji Tygodnia Języka Ojczystego. Angażują się również w wydarzenia o szerszym zasięgu typu Ogólnopolskie Dyktando oraz konferencje międzynarodowe, wspierają merytorycznie i autorsko inicjatywy regionalne, współpracują z Uniwersytetem Trzeciego Wieku i placówkami edukacyjnymi.

Zarysowane w tym szkicu dokonania zespołu dydaktyków trzeba dziś opatrzyć formułą: „Była sobie raz Katedra”. „Była...”, ale pozostaną ludzie, więzi, które ich łączyły i które umacniały się we współdziałaniu. Pozostaną efekty ich badań. Pozostanie DOBRO — dla nauki, dla szkoły, dla środowiska uczynione.

\section{Bibliografia}

Adamczykowa Z.: Mieczysława Mitera-Dobrowolska (1900-1992). Katowice 2006.

Bartmiński J.: Miejsce wartości w językowym obrazie świata. W: Idem: Język w kręgu wartości. Studia semantyczne. Red. J. Bartmiński. Lublin 2003.

Bartmiński J.: O pojęciu językowego obrazu świata. W: Idem: Językowe podstawy obrazu świata. Lublin 2006.

Bula D., Krzyżyk D., Niesporek-Szamburska B., Synowiec H.: Dziecko w świecie języka. Kraków 2004.

Bula D., Niesporek-Szamburska B.: Zachowania językowe młodzieży - błędy w komunikacji czy celowa manifestacja?. W: Język trzeciego tysiaclecia 2. T. 1: Nowe oblicze komunikacji we wspótczesnej polszczyźnie. Red. G. Szpila. Kraków 2002.

Cofalik J., Nowakowa Z., Polański E., Przyklenk E., Tabakowska I.: Nauczanie języka polskiego w klasie $V$. Warszawa 1973.

Cofalik J., Tabakowska I.: Kształtowanie języka ucznia w procesie nauczania języka polskiego. Warszawa 1963.

Cofalik J., Tabakowska I., Nowakowski M.: Poprawa wypracowań pisemnych z języka polskiego. Katowice 1957.

Cząstka-Szymon B., Synowiec H.: Charakterystyka gwar śląskich na tle zróżnicowania dialektalnego województwa ślaskiego. W: Ex pago Silensi. Red. M. Kisie1, T. Sierny. Katowice 2011.

Gąsiorek K.: Komunikatywność (czytelność) podręczników literatury a język uczniów w szkole średniej. W: Podręczniki literatury w szkole średniej. Red. B. Chrząstow ska. Poznań 1991. 
Guzy A.: Jakość emisji głosu przyszłych nauczycieli. W: Językowe, literackie i kulturowe ścieżki edukacji polonistycznej (tradycje i wspótczesność). Red. B. Niesporek-Szamburska, D. Krzyżyk. Katowice 2014.

Guzy A.: Problemy głosowe nauczycieli. W: Zdrowie $w$ perspektywie pedagogicznej. Red. D. Umiastowska, J. Gebreselassie. Gorzów Wielkopolski 2012.

Guzy A.: Rola ortofonii w edukacji obcokrajowców - rozwiazania praktyczne. W: Polska i Polacy w badaniach młodych naukowców. Red. N. Kryłowa, A. Izaszko, J. Jędrysiak, T. Goli-Ogłu. Mariupol 2009.

Guzy A.: Szybkość czytania a sprawność ortograficzna uczniów w klasach III-VI. W: „Z Teorii i Praktyki Dydaktycznej Języka Polskiego”. T. 19. Red. H. Synowiec. Katowice 2007.

Jasnopis, czyli mierzenie zrozumiałości polskich tekstów urzędowych. Red. W. Gruszczyński, M. Ogrodniczuk. Warszawa 2015.

Językowy obraz świata. Red. J. Bartmiński. Lublin 1990.

Kopeć U.: Rozwój stownictwa nazywającego uczucia w języku dzieci i młodzieży. Rzeszów 2000.

Kram J.: Gawędy o żywym stowie. Warszawa 1976.

Kram J.: Zarys kultury żywego stowa. Warszawa 1981.

Krzyżyk D.: Językowo-kulturowy obraz św. Barbary w pieśniach religijnych i powszechnych. W: Dziedzictwo kulturowo-historyczne regionu. Red. A. Królikowska. Kraków 2013.

Krzyżyk D.: Językowy obraz prawdy w wypowiedziach młodzieży szkót średnich. W: „Z Teorii i Praktyki Dydaktycznej Języka Polskiego”. T. 16. Red. H. Synowiec. Katowice 2001.

Krzyżyk D.: Odzwierciedlenie funkcji podręcznika w języku i stylu. W: „Opinie Edukacyjne Polskiej Akademii Umiejętności - Prace Komisji PAU do Oceny Podręczników Szkolnych”. T. 13. Red. G. Chomicki. Kraków 2015.

Krzyżyk D.: Odzwierciedlenie języka i kultury regionu w pieśniach górniczych. W: „Z Teorii i Praktyki Dydaktycznej Języka Polskiego". T. 20. Red. H. Synowiec. Katowice 2009.

Krzyżyk D.: Pieśni dla Dziecka i o Dziecku. Cud narodzin Boga w kolędach polskich (wybrane motywy). W: Dziecko - język - tekst. Red. B. Niesporek-Szamburska, M. Wójcik-Dudek. Katowice 2010.

Krzyżyk D.: Rozwój umiejętności pisania uczniów z dysleksją rozwojowa - ćwiczenia wspomagające kształcenie kompetencji komunikacyjno-językowej. W: Profilaktyka logopedyczna w praktyce edukacyjnej. T. 2. Red. K. Węsierska, N. Moćko. Katowice 2013.

Krzyżyk D.: Synonimia pojęć prawdziwościowych. Teoria i nauczanie. Katowice 2008.

Krzyżyk D.: Uczeńw krainie ortografii. W: D. Bula, D. Krzyżyk, B. Niesporek-Szamburska, H. Synowiec: Dziecko w świecie języka. Kraków 2004.

Krzyżyk D.: Umiejętności tekstotwórcze i językowe uczniów w pisemnych wypowiedziach maturalnych. W: Ksztatcenie językowe w dobie kultury masowej polisensorycznej. Red. U. Kopeć, Z. Sibiga. Rzeszów 2010.

Krzyżyk D.: Wizerunek górnika w przystowiach. W: Ex pago Silensi. Red. M. Kisie1, T. Sierny. Katowice 2011.

Krzyżyk D.: Wyznaczniki spójności tekstu w pracach pisemnych maturzystów. W: Biuletyn maturalny OKE w Jaworznie. Cz. 2. Jaworzno 2007.

Krzyżyk D.: Znajomość związków frazeologicznych o rodowodzie mitologicznym (na podstawie badań wśród studentów). W: Język żyje. Rzecz o wspótczesnej polszczyźnie. Red. K. Ożóg. Rzeszów 2009.

Krzyżyk D., Leś W., Synowiec H.: Spotkania z gwara i kulturą regionu. Konkurs recytatorski w gwarze śląskiej Śląska Ojczyzna Polszczyzna. Mysłowice 2007.

Krzyżyk D., Synowiec H.: Etyka stowa w rozumieniu młodzieży. W: Etyka stowa. Wybór opracowań. Red. J. Bartmiński, S. Niebrzegowska-Bartmińska, M. Nowosad-Bakalarczyk, J. Puzynina. Lublin 2017. 
Krzyżyk D., Synowiec H.: Homilie dla dzieci. Spojrzenie językoznawcy. W: Słowo, obraz, dźwięk w mszach świętych z udziałem dzieci. Red. H. Sławiński, W. Przyczyna. Kraków 2019.

Krzyżyk D., Synowiec H.: Językowa projekcja domu rodzinnego w wypowiedziach młodzieży śląskiej. W: Rodzina, wychowanie, wielokulturowość. Red. T. Lewowicki, J. Suchodolska. Cieszyn 2000.

Krzyżyk D., Synowiec H.: O błędach w pisemnych wypowiedziach polonistów (na podstawie analizy opinii o studentach). W: Norma językowa w aspekcie teoretycznym i praktycznym. Red.

A. Piotrowicz, M. Witaszek-Samborska, K. Skibski. Poznań 2011.

Krzyżyk D., Synowiec H.: Podręcznik szkolny - pomoc czy przeszkoda w opanowaniu wiedzy i umiejętności (komunikatywność i funkcjonalność)?. W: Oblicza polszczyzny. Red. A. Markowski, R. Pawelec. Warszawa 2012.

Krzyżyk D., Synowiec H.: Teksty hagiograficzne dla dzieci w „,Małym Gościu Niedzielnym”. W: „Stare $i$ nowe” $w$ literaturze dla dzieci i młodzieży. Biografie. Red. B. Olszewska, O. Pajączkowski, L. Urbańczyk. Opole 2015.

Krzyżyk D., Synowiec H.: Tytuły podręczników do kształcenia polonistycznego - ich formuly i funkcje. W: „Opinie Edukacyjne Polskiej Akademii Umiejętności — Prace Komisji PAU do Oceny Podręczników Szkolnych”. T. 15. Red. G. Chomicki. Kraków 2017.

Krzyżyk D., Synowiec H.: Z badań nad zwiazkami frazeologicznymi z komponentami nazw barw w języku uczniów (wyniki badań i propozycje dydaktyczne). W: W trosce o dobra edukację. Red. A. Janus-Sitarz. Kraków 2009.

Łojek M.: Droga Edwarda Polańskiego do profesury. W: W kręgu zagadnień dydaktyki języka i literatury polskiej. Red. H. Synowiec. Katowice 2002.

Łojek M.: Mieczystawa Mitera-Dobrowolska. Wzór polonistki na dziś i na jutro. Bydgoszcz 1998.

Mikuta M.: Kultura żywego stowa. Warszawa 1961.

Niesporek-Szamburska B.: Język pierwszy dziecka - od nabywania do kształcenia kompetencji językowej i komunikacyjnej. W: Lingwistyka stosowana. T. 3. Red. S. Grucza. Warszawa 2010.

Niesporek-Szamburska B.: Język wierszy dla dzieci (na materiale „Świerszczyka”). Katowice 1990.

Niesporek-Szamburska B.: Językowy obraz pór roku i tradycji kulturowych w twórczości dzieci. Katowice 2004.

Niesporek-Szamburska B.: Literatura fantasy w edukacji polonistycznej. W: Kultura, literatura i sztuka w edukacji językowej w świetle badań empirycznych. Red. J. Kida. Rzeszów 2007.

Niesporek-Szamburska B.: Media elektroniczne a język ucznia. W: Ksztatcenie językowe w dobie kultury masowej polisensorycznej. Red. U. Kopeć, Z. Sibiga. Rzeszów 2010.

Niesporek-Szamburska B.: O metaforze synestezyjnej w tekstach dzieci. W: „Z Teorii i Praktyki Dydaktycznej Języka Polskiego". T. 18. Red. H. Synowiec. Katowice 2005.

Niesporek-Szambursk a B.: Stereotyp czarownicy i jego modyfikowanie. Na przykladzie tekstów dla dzieci i wypowiedzi dziecięcych. Katowice 2013.

Niesporek-Szamburska B.: Wiersze dla dzieci jako komunikat w prasie (na przyktadzie „Świerszczyka”). W: „Język Artystyczny”. T. 5. Red. A. Wilkoń. Katowice 1987.

Pedagogika szkolna. Materiały dla studentów przygotowujacych się do wykonywania zawodu nauczyciela. Red. D. Krzyżyk, B. Niesporek-Szamburska przy współpracy A. Zok-Smoły. Katowice 2014.

Podręczniki do ksztatcenia polonistycznego $w$ zreformowanej szkole — koncepcje, funkcje, język. Red. H. Synowiec. Katowice 2007.

Polański E.: Badania nad ortografią uczniów. Katowice 1969.

Polański E.: Dydaktyka ortografii i interpunkcji. Wyd. 1. - Warszawa 1987. Wyd. 2. — Warszawa 1995.

Polański E.: Stownictwo uczniów. Problemy, badania, wnioski. Warszawa 1982. 
Potaś M.: Metafora $w$ tekstach pisanych uczniów. Praca doktorska napisana pod kierunkiem H. Synowiec w roku 2007. APD Uniwersytetu Pedagogicznego w Krakowie.

Praca z uczniem o specjalnych potrzebach edukacyjnych. T. 1. Red. A. Guzy, D. Krzyżyk. Kielce 2012.

Praca z uczniem o specjalnych potrzebach edukacyjnych. T. 2. Red. A. Guzy, B. Niesporek-Szamburska. Kielce 2013.

Przybyla O.: Akty mowy w języku nauczyciela. Katowice 2004.

Rypel A.: Nauczanie komunikacyjne w kształceniu uczniowskich wypowiedzi pisemnych. Problemy. Badania eksperymentalne. Implikacje dydaktyczne. Bydgoszcz 2000.

Skowronek B.: O dialogu na lekcjach w szkole średniej. Analiza pragmatycznojęzykowa. Kraków 1999. Rozprawa doktorska przygotowana pod kierunkiem Heleny Synowiec. APD Uniwersytetu Pedagogicznego w Krakowie.

Synowiec H.: Kultura języka nauczycieli w sytuacji lekcyjnej. W: Dyskurs edukacyjny. Red. T. Rittel. Kraków 1996.

Synowiec H.: O kulturze języka we wspótczesnej szkole. W: W kręgu polszczyzny dawnej a wspótczesnej. Księga ofiarowana dr. hab. Kazimierzowi Dlugoszowi, profesorowi Uniwersytetu Szczecińskiego. Red. E. Kołodziejek. Szczecin 2006.

Synowiec H.: O przydatności badań glottodydaktycznych w nauczaniu języka ojczystego w środowiskach gwarowych. „Języki Obce w Szkole” 2001, nr 6.

Synowiec H.: Problemy frazeologii w kształceniu językowym uczniów. W: Wiedza o języku i kompetencje językowe uczniów. Red. B. Niesporek-Szamburska. Katowice 2012.

Synowiec H.: Rozwój słownictwa nazywającego cechy osobowości w języku dzieci i młodzieży. Katowice 1985.

Synowiec H.: Stużyć nauce i szkole. Działalność naukowa i dydaktyczna prof. dr. hab. Edwarda Polańskiego. W: W kręgu zagadnień dydaktyki języka i literatury polskiej. Red. H. Synowiec. Katowice 2002.

Synowiec H.: Sposoby popularyzowania polszczyzny pięknej i poprawnej w poradnikach językowych dla dzieci i młodzieży. W: Lektury pokoleniowe i ponadpokoleniowe. Z zagadnień recepcji. Red. I. Socha. Katowice 2012.

Synowiec H.: Sprawność językowa uczniów w ślaskim środowisku gwarowym. Problemy, badania, konsekwencje dydaktyczne. Katowice 1992.

Synowiec H.: Stan polszczyzny uczniów na tle przemian kulturowych i cywilizacyjnych. W: Język polski jako narzędzie komunikacji we współczesnym świecie. Red. J. Mazur, M. Rzeszutko-Iw an. Lublin 2007.

Synowiec H.: Ślaska ojczyzna polszczyzna z perspektywy edukacyjnej. Katowice 2013.

Synowiec H.: Ślaskie czasopisma szkolne (1922-1938). Katowice 1999.

Synowiec H.: Uczeń wśród słów, związków frazeologicznych i regionalnych odmian polszczyzny. W: D. Bula, D. Krzyżyk, B. Niesporek-Szamburska, H. Synowiec: Dziecko w świecie języka. Kraków 2004.

Synowiec H.: Wizerunek myśliwego w pieśniach ludowych. W: Wokót kultury myśliwskiej. Szkice o tradycjach łowieckich ziemi pszczyńskiej. Red. J. Uchyła-Zroski, R. Solik. Pszczyna 2008.

Synowiec H.: Zróżnicowanie terytorialne polszczyzny a edukacja językowa. W: Odmiany polszczyzny w szkole. Teoria i praktyka. Red. H. Synowiec przy współpracy M. Kubarek. Katowice 2013.

Szymańska M.: Metafory w twórczych wypowiedziach pisemnych uczniów. Kraków 2012.

Tabakowska I.: O szkolnych niepowodzeniach $w$ nauczaniu gramatyki i ich źródłach. „Polonistyka" 1964, z. 2. 
Tabakowska I.: Oznajmienie imiesłowowe w języku pisanym uczniów starszych klas szkoły podstawowej na Śląsku. „Język Polski” 1967, z. 2.

Tabakowska I.: Próby programowanego nauczania gramatyki polskiej w szkołach podstawowych województwa katowickiego. W: „Prace Dydaktyczne” VII. Red. J. Cofalik. Katowice 1975.

Tabakowska I.: Trudności składni w języku pisanym młodzieży starszych klas szkoły podstawowej. W: „Zeszyty Naukowe Katedry Metodyki Literatury i Języka Polskiego WSP”. Nr 1. Katowice 1963.

Zgółka T.: Kształcenie językowe a językoznawstwo wspótczesne. W: Zjazd polonistów 1995. (Zagadnienia edukacyjne). Red. B. Chrząstowska, Z. Uryga. Kraków 1995.

Żydek-Bednarczuk U.: Uczeń i nauczyciel $w$ świecie dyskursów. W: „Studia Pragmalingwistyczne”. T. 5: Mowa i język w perspektywie dydaktycznej, logopedycznej i rozwojowej. Red. J. Porayski-Pomsta. Warszawa 2008.

Żydek-Bednarczuk U.: Opowiadania szkolne $w$ świetle diagnozy dydaktycznej. W: „Z Teorii i Praktyki Dydaktycznej Języka Polskiego”. T. 15. Red. E. Polański, Z. Uryga. KatowiceKraków 1999.

Żydek-Bednarczuk U., Zeler B.: Strategia i komunikacja $w$ dyskursie edukacyjnym. W: Dyskurs edukacyjny. Red. T. Rittel. Kraków 1996. 